\title{
Exploration of novel thiobarbituric acid-, rhodanine- and thiohydantoin-based HIV-1 integrase inhibitors
}

\author{
Suvi Rajamaki ${ }^{a}$, Anna Innitzer ${ }^{a}$, Chiara Falciani $^{a}$, Cristina Tintori $^{a}$, Frauke Christ ${ }^{\mathrm{b}}$, Myriam Witvrouw $^{\mathrm{b}}$, \\ Zeger Debyser $^{\mathrm{b}}$, Silvio Massa ${ }^{\mathrm{a}}$, Maurizio Botta ${ }^{\mathrm{a}, *}$ \\ a Dipartimento Farmaco Chimico Tecnologico, Università degli Studi di Siena, Via A. De Gasperi 2, I-53100 Siena, Italy \\ ${ }^{\mathrm{b}}$ Molecular Medicine, Katholieke Universiteit Leuven, Kapucijnenvoer 33, B-3000 Leuven, Flanders, Belgium
}

\section{A R T I C L E I N F O}

\section{Article history:}

Received 11 February 2009

Revised 24 April 2009

Accepted 25 April 2009

Available online 3 May 2009

\section{Keywords:}

HIV-1

Integrase inhibitors

SAR study

Thiobarbituric acid

Rhodanine

Thiohydantoin

\begin{abstract}
A B S T R A C T
A novel compound inhibiting HIV-1 integrase has been identified by means of virtual screening techniques. A small family of structurally related molecules has been synthesized and biologically evaluated with some of the compounds possessing micromolar activity both in enzymatic and cellular assays.
\end{abstract}

(c) 2009 Elsevier Ltd. All rights reserved.
Until very recently four different classes of drugs have been approved by the FDA in the treatment of HIV infection: (i) nucleoside reverse transcriptase inhibitors, (ii) non-nucleoside reverse transcriptase inhibitors, (iii) protease inhibitors and (iv) fusion inhibitors. ${ }^{1}$ These drugs have proven to be successful for treatment of HIV-1 infection, but their adverse effects together with the emergence of resistant mutant strains calls for development of new therapies against the virus. ${ }^{2}$

HIV-1 integrase (IN) is an essential enzyme for the integration of viral DNA into the host cell genome. The process occurs in two spatially and temporally distinct steps known as $3^{\prime}$ processing and strand transfer. The $3^{\prime}$ processing occurs in the cytoplasm, where IN binds the viral DNA and then removes a dinucleotide adjacent to a conserved CA sequence from the $3^{\prime}$ end of each strand.

The formed complex is then transported into the nucleus, where the strand transfer reaction takes place and the $3^{\prime}$ ends of the viral DNA are covalently linked to the $5^{\prime}$ ends of the host cell DNA. ${ }^{3}$ The crucial role of IN in the viral replication cycle makes it an interesting target for the development of new anti-HIV therapies.

Over the last decade, there have been extensive studies performed towards finding new drugs able to inhibit IN, resulting in

\footnotetext{
* Corresponding author. Tel.: +390577 234306; fax: +390577 234333.

E-mail address: botta@unisi.it (M. Botta).
}

a vast number of compounds reported to inhibit IN in biochemical assays. ${ }^{4}$ In 2007, this research culminated in the approval of raltegravir (MK-0518) by the FDA ${ }^{5}$ which displays the first example of the fifth class of drugs active against HIV-1. ${ }^{6}$

We recently disclosed our own work in the field by presenting the design, synthesis and biological evaluation of a small family of a structurally novel class of IN inhibitors (Chart 1$){ }^{7}$

Despite the promising biological results in enzymatic assays, none of the tested compounds was able to inhibit HIV replication at subtoxic concentrations.

In this work, pursuing our intention to identify novel HIV-1 IN inhibitors able to affect the IN-viral DNA complex formation, a new structure-based virtual screening protocol has been applied. ${ }^{8}$

In particular, since the DNA binding site of IN is characterized by a non-rigid region (namely, the loop 140-149), the flexibility of this loop was taken into account by means of a conformational search study and the most representative conformations were used to generate different receptor-based pharmacophoric models. The receptor-based pharmacophoric models were used in turn to screen all compounds of the Asinex Gold Collection Database ${ }^{9}$ followed by the evaluation of the binding energy of the selected molecules and by docking calculations. On the basis of three different criterions, (i) the matching between the compound interactions and the pharmacophoric features, (ii) the consensus score and (iii) the diversity of the structural scaffolds, a group of ten compounds was submitted to biological investigation. 


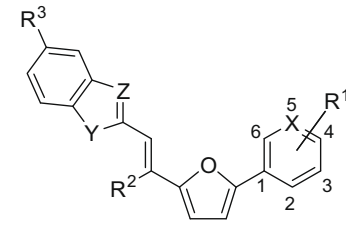

Chart 1. First generation IN inhibitors reported by our group.

As a result, one of the compounds, namely 12a (Asinex code: BAS-0442494) was identified showing significant inhibitory potency against IN (Table 1 ). Unlike the previously reported compounds, 12a proved also to moderately inhibit HIV-1 replication in cells at micromolar concentration. Moreover, this compound represents a new scaffold in the field of HIV IN inhibitors.

With the new hit compound in our hand, we started an extensive SAR study. Thus, 12a was divided into three portions in order to analyze the specific impact of each of these components on the activity against IN (Chart 2 ).

Initially we focused on thiobarbituric acid-based potential inhibitors of IN (12a-1, Table 1) and therefore varied the aromatic linker (part B) and the substituents of the phenyl moiety (part C). The data of the enzymatic and cellular tests are presented in Table 1. The potency of the compound could be slightly improved by the

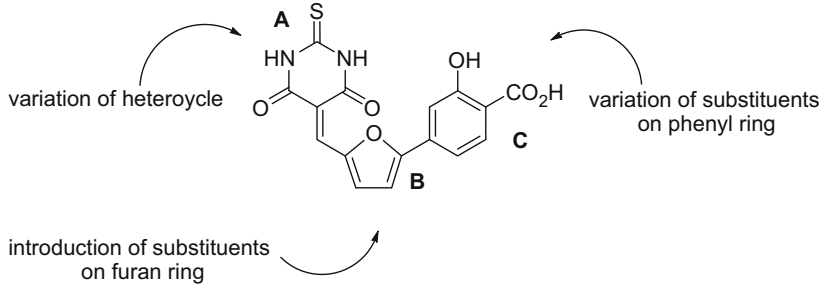

Chart 2. Structure-activity relationship study.

introduction of an additional hydroxyl group on the phenyl moiety (12g, Table 1) whereas all other modifications led to compounds with inferior activity in the enzymatic assays. Also, introduction of a methyl substituent at position 5 of the furan ring did not lead to an improvement of the activity of the compounds (compare entries 12a and 12l, Table 1). Next, various potential inhibitors with other heterocyclic moieties than thiobarbituric acid namely rhodanine and thiohydantoin were synthesized and biologically evaluated (13a-p, 14a,b,l, Table 1).

One compound (13g, Table 1 ) could be identified having a slightly improved therapeutic index compared to the best $(\mathbf{1 2 g}$, Table 1 ) from the thiobarbituric acid-based series of compounds.

Table 1

Cytotoxicity, anti-integrase and antiviral activities of compounds 12-14<smiles>[R]c1ccc(-c2cc([R])c(C=C3C(=O)NC(=S)NC3=O)o2)cc1</smiles>

$12 \mathrm{a}-12 \mathrm{I}$

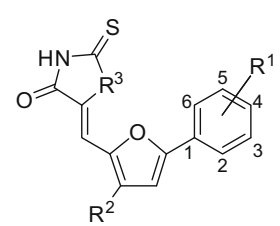

$\mathrm{R}^{3}=\mathrm{S} \quad 13 \mathrm{a}, \mathbf{d}, \mathbf{e}, \mathrm{g}, \mathrm{I}, \mathrm{p}$

$\mathrm{R}^{3}=\mathrm{NH} 14 \mathrm{a}, \mathrm{b}, \mathrm{I}$

\begin{tabular}{|c|c|c|c|c|c|c|c|c|c|}
\hline \multirow[t]{2}{*}{ Compd } & \multirow[t]{2}{*}{$\mathrm{R}^{1}$} & \multirow[t]{2}{*}{$\mathrm{R}^{2}$} & \multirow[t]{2}{*}{$\mathrm{R}^{3}$} & \multirow[t]{2}{*}{ Over-all $\mathrm{IC}_{50}^{\mathrm{a}}$} & \multicolumn{2}{|c|}{ IN enzymatic activity } & \multicolumn{3}{|c|}{ Antiviral activity } \\
\hline & & & & & $\mathrm{ST} \mathrm{IC}_{50}^{\mathrm{b}}$ & $3^{\prime} \mathrm{IC}_{50}{ }^{\mathrm{c}}$ & $\mathrm{EC}_{50}^{\mathrm{d}}$ & $\mathrm{CC}_{50} \mathrm{e}^{\mathrm{e}}$ & T.I. $^{f}$ \\
\hline $12 a$ & $4-\mathrm{CO}_{2} \mathrm{H}, 5-\mathrm{OH}$ & $\mathbf{H}$ & - & $8.94( \pm 0.01)$ & $2.74( \pm 1.92)$ & $69.16( \pm 39.7)$ & 30 & 60 & 2 \\
\hline 12b & $4-\mathrm{OH}, 5-\mathrm{CO}_{2} \mathrm{H}$ & $\mathrm{H}$ & - & $33.4( \pm 1.34)$ & $53.0( \pm 6.98)$ & nt & $>222.1$ & 222.1 & - \\
\hline $12 c$ & $2-\mathrm{CO}_{2} \mathrm{H}, 4-\mathrm{F}$ & $\mathrm{H}$ & - & $184.4( \pm 77.2)$ & $47.1( \pm 7.9)$ & nt & $>164.9$ & 164.9 & - \\
\hline 12d & $4-\mathrm{Cl}, 5-\mathrm{CO}_{2} \mathrm{H}$ & $\mathrm{H}$ & - & $41.7( \pm 2.07)$ & $12.86( \pm 1.19)$ & nt & $>152.3$ & 152.3 & - \\
\hline $12 e$ & $2-\mathrm{Cl}, 4-\mathrm{CO}_{2} \mathrm{H}, 5-\mathrm{OMe}$ & $\mathrm{H}$ & - & $43.2( \pm 12.2)$ & $35.3( \pm 10.0)$ & nt & $>100.2$ & 100.2 & - \\
\hline $12 f$ & $2-\mathrm{OH}, 3-\mathrm{CO}_{2} \mathrm{H}$ & $\mathrm{H}$ & - & $>250$ & $>250$ & nt & $>139.7$ & 139.7 & - \\
\hline $12 \mathrm{~g}$ & $2,3-\mathrm{OH}, 5-\mathrm{CO}_{2} \mathrm{H}$ & $\mathbf{H}$ & - & $5.06( \pm 2.17)$ & $5.79( \pm 1.82)$ & $>\mathbf{2 5 0}$ & $54.7( \pm 24.5)$ & $138.1( \pm 63.3)$ & 3 \\
\hline $12 \mathrm{~h}$ & $2-\mathrm{Me}, 5-\mathrm{CO}_{2} \mathrm{H}$ & $\mathrm{H}$ & - & $46.35( \pm 2.19)$ & $25.4( \pm 8.20)$ & nt & $>158.8$ & 158.8 & - \\
\hline $12 \mathbf{i}$ & 2,6-OMe, $4-\mathrm{CO}_{2} \mathrm{H}$ & $\mathrm{H}$ & - & $167.2( \pm 51.7)$ & $>250$ & nt & $>61.1$ & 61.1 & - \\
\hline $12 \mathbf{j}$ & 2-Me, 3- $\mathrm{NO}_{2}$ & $\mathrm{H}$ & - & $58.4( \pm 24.5)$ & $40.8( \pm 12.7)$ & nt & $>17.9$ & 17.9 & - \\
\hline 12k & $2,3-\mathrm{O}-\mathrm{CH}_{2}-\mathrm{O}, 5-\mathrm{CO}_{2} \mathrm{H}$ & $\mathrm{H}$ & - & $56.5( \pm 22.2)$ & $71.57( \pm 8.77)$ & nt & $>125$ & $>125$ & - \\
\hline 121 & $4-\mathrm{CO}_{2} \mathrm{H}, 5-\mathrm{OH}$ & Me & - & $90.87( \pm 5.13)$ & $125.01( \pm 5.01)$ & nt & $>125$ & $>125$ & - \\
\hline 13a & $4-\mathrm{CO}_{2} \mathrm{H}, 5-\mathrm{OH}$ & $\mathbf{H}$ & $\mathbf{S}$ & $182( \pm 44.9)$ & $>250$ & 97.72( \pm 42.94$)$ & 30.1 & $>72.0$ & 2 \\
\hline 13d & $4-\mathrm{Cl}, 5-\mathrm{CO}_{2} \mathrm{H}$ & $\mathrm{H}$ & $\mathrm{S}$ & $>250$ & $>250$ & nt & $>154.6$ & 154.6 & - \\
\hline $13 e$ & $2-\mathrm{Cl}, 4-\mathrm{CO}_{2} \mathrm{H}, 5-\mathrm{OMe}$ & $\mathrm{H}$ & $\mathrm{S}$ & $>250$ & $>250$ & nt & $>142.8$ & 142.8 & - \\
\hline $13 g$ & 2,3-OH, 5- $\mathrm{CO}_{2} \mathrm{H}$ & $\mathbf{H}$ & $\mathbf{S}$ & $15.47( \pm 8.38)$ & $22.3( \pm 5.22)$ & $164( \pm 18.6)$ & 17.97 & 131.2 & 7 \\
\hline 131 & $4-\mathrm{CO}_{2} \mathrm{H}, 5-\mathrm{OH}$ & $\mathrm{Me}$ & $\mathrm{S}$ & $157.95( \pm 7.85)$ & $134.58( \pm 35.8)$ & nt & $\mathrm{nt}^{\mathrm{g}}$ & nt & - \\
\hline 13p & $4-\mathrm{CO}_{2} \mathrm{H}, 5-\mathrm{OH}$ & OMe & $S$ & $>250$ & $>250$ & $\mathrm{nt}$ & 112.4 & $>125$ & - \\
\hline $14 a$ & $4-\mathrm{CO}_{2} \mathrm{H}, 5-\mathrm{OH}$ & $\mathrm{H}$ & $\mathrm{NH}$ & $107( \pm 7.96)$ & $74.0( \pm 6.6)$ & nt & $>193.4$ & 193.4 & - \\
\hline $14 b$ & $4-\mathrm{OH}, 5-\mathrm{CO}_{2} \mathrm{H}$ & $\mathbf{H}$ & NH & $50.9( \pm 7.96)$ & $>250$ & $>250$ & 95.2 & 151.5 & 2 \\
\hline 141 & $4-\mathrm{CO}_{2} \mathrm{H}, 5-\mathrm{OH}$ & Me & $\mathrm{NH}$ & $>250$ & $>250$ & nt & nt & nt & - \\
\hline МК0518 & & & & $0.08( \pm 0.012)$ & $0.067( \pm 0.006)$ & - & $0.0064( \pm 0.0011)$ & $142.73( \pm 0.82)$ & 22302 \\
\hline
\end{tabular}

Values are means of three experiments; standard deviation is given in parentheses.

a Concentration $(\mu \mathrm{M})$ required to inhibit the in vitro over-all integrase activity by $50 \% .{ }^{16}$

b Concentration $(\mu \mathrm{M})$ required to inhibit the in vitro strand transfer step by $50 \%{ }^{16}$

c Concentration $(\mu \mathrm{M})$ required to inhibit the in vitro $3^{\prime}$-processing step by $50 \%{ }^{16}$

${ }^{d}$ Effective concentration $(\mu \mathrm{M})$ required to reduce HIV-1-induced cytopathic effect by 50\% in MT-4 cells. ${ }^{16}$

e Cytotoxic concentration $(\mu \mathrm{M})$ to reduce MT-4 cell viability by $50 \%{ }^{16}$

f Therapeutic index $=\mathrm{CC}_{50} / \mathrm{EC}_{50}$

g nt: not tested. 


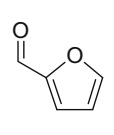

1
$2 \mathrm{a}-2 \mathrm{~g}$

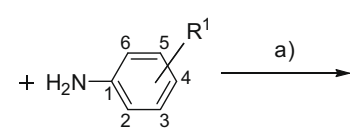

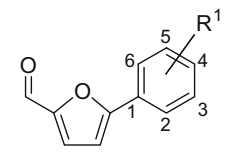

$3 a-3 g$
Scheme 1. Meerwein arylation procedure used for the assembly of aryl aldehydes 3a-g. Reagents and conditions: (a) (i) $\mathbf{2 a}-\mathbf{g}, \mathrm{NaNO}_{2}, \mathrm{HBF}_{4}, \mathrm{H}_{2} \mathrm{O}, 0^{\circ} \mathrm{C}$; (ii) $\mathrm{CuCl}_{2}$, acetone, rt. 3a: $\mathrm{R}^{1}=4-\mathrm{CO}_{2} \mathrm{H}, 5-\mathrm{OH} . \mathbf{3 b}: \mathrm{R}^{1}=4-\mathrm{OH}, 5-\mathrm{CO}_{2} \mathrm{H}$. 3c: $\mathrm{R}^{1}=2-\mathrm{CO}_{2} \mathrm{H}, 4-\mathrm{F}$. 3d: $\mathrm{R}^{1}=4-\mathrm{Cl}, 5-\mathrm{CO}_{2} \mathrm{H}$. 3e: $\mathrm{R}^{1}=2-\mathrm{Cl}, 4-\mathrm{CO}_{2} \mathrm{H}, 5-\mathrm{OMe}$. 3f: $\mathrm{R}^{1}=2-\mathrm{OH}, 3-\mathrm{CO}_{2} \mathrm{H} .3 \mathrm{~g}: \mathrm{R}^{1}=2-$ $\mathrm{OH}, 3-\mathrm{OH}, 5-\mathrm{CO}_{2} \mathrm{H}$

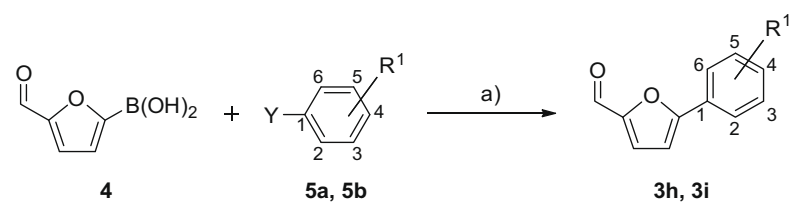

Scheme 2. Suzuki coupling strategy for the assembly of aryl aldehydes $\mathbf{3 h}-\mathbf{j}$. Reagents and conditions: (a) $\mathbf{5 a}$ or $\mathbf{5 b}, \mathrm{Pd}\left(\mathrm{PPh}_{3}\right)_{2} \mathrm{Cl}_{2}, \mathrm{Na}_{2} \mathrm{CO}_{3}, \mathrm{EtOH}, \mathrm{DME}, 50{ }^{\circ} \mathrm{C}$. $\mathbf{3 h}$ : $\mathrm{R}^{1}=2-\mathrm{Me}, 5-\mathrm{CO}_{2} \mathrm{H} .3 \mathrm{i}: \mathrm{R}^{1}=2,6-\mathrm{OMe}, 4-\mathrm{CO}_{2} \mathrm{H}$.

In order to gain insight into the mechanism of action, some compounds were also submitted to $3^{\prime}$-processing assays (Table 1). However, it seems from the obtained data, that classical in vitro testing is not sufficient for the classification of these novel IN inhibitors. ${ }^{10}$

Synthesis of the desired compounds was accomplished by a straight forward strategy. This involved first the synthesis of differently substituted biaryl aldehydes and subsequent Knoevenagel condensation with thiobarbituric acid, rhodanine or thiohydantoin. The furaldehydes necessary for the condensation reactions with thiobarbituric acid and rhodanine were either purchased or synthesised by three different methods.

The majority of the biaryl aldehydes could be obtained by a Meerwein arylation. ${ }^{11}$ This involved the formation of a diazonium salt from suitable substituted aniline (2a-g) and subsequent $\mathrm{Cu}$ (II) mediated coupling reaction with furfural to give the desired aromatic aldehydes in good yields (Scheme 1).

Alternatively, the desired products were obtained by a Suzuki coupling reaction ${ }^{12}$ between an appropriate substituted phenyl halide and 5-formyl-2-furanboronic acid using $\mathrm{Pd}\left(\mathrm{PPh}_{3}\right)_{2} \mathrm{Cl}_{2}$ as the catalyst and an aqueous solution of $\mathrm{Na}_{2} \mathrm{CO}_{3}$ as the base (Scheme 2).

Attempts to use the Meerwein protocol or a Suzuki reaction for the synthesis of the biaryl aldehydes $8,11 \mathbf{a}$ and $\mathbf{1 1 b}$ led either to
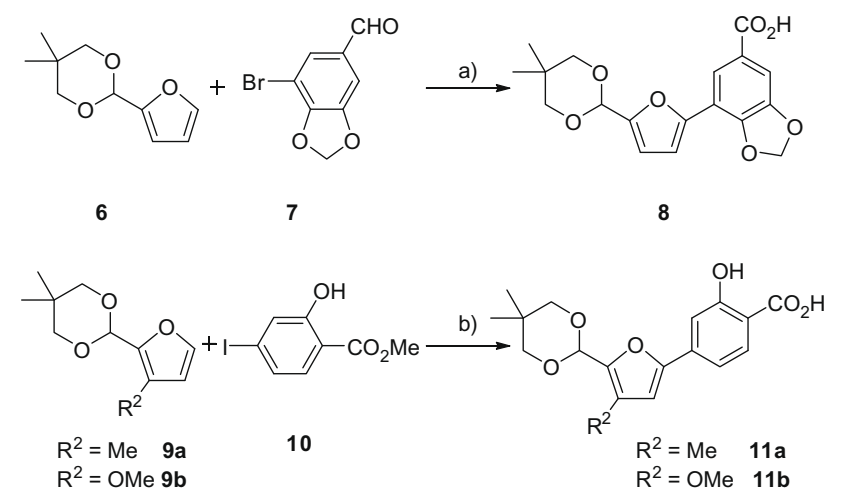

Scheme 3. Heck coupling strategy for the assembly of aryl aldehydes $\mathbf{8}$ and $\mathbf{1 1}$. Reagents and conditions: (a) (i) $\mathrm{PdCl}_{2}, \mathrm{Cy}_{3} \mathrm{P}, \mathrm{Bu}_{4} \mathrm{NBr}, \mathrm{KOAc}, \mathrm{DMF}, 110^{\circ} \mathrm{C}$; (ii) $\mathrm{NaClO}_{2}$, $\mathrm{KH}_{2} \mathrm{PO}_{4}, 2$,3-dimethyl-2-butene, $t$ - $\mathrm{BuOH}, \mathrm{H}_{2} \mathrm{O}$, rt; (b) (i) $\mathrm{PdCl}_{2}, \mathrm{Cy}_{3} \mathrm{P}, \mathrm{Bu}_{4} \mathrm{NBr}, \mathrm{KOAc}$, $\mathrm{DMF}, 110^{\circ} \mathrm{C}$; (ii) $\mathrm{NaOH}, \mathrm{THF}, \mathrm{MeOH}$, reflux.

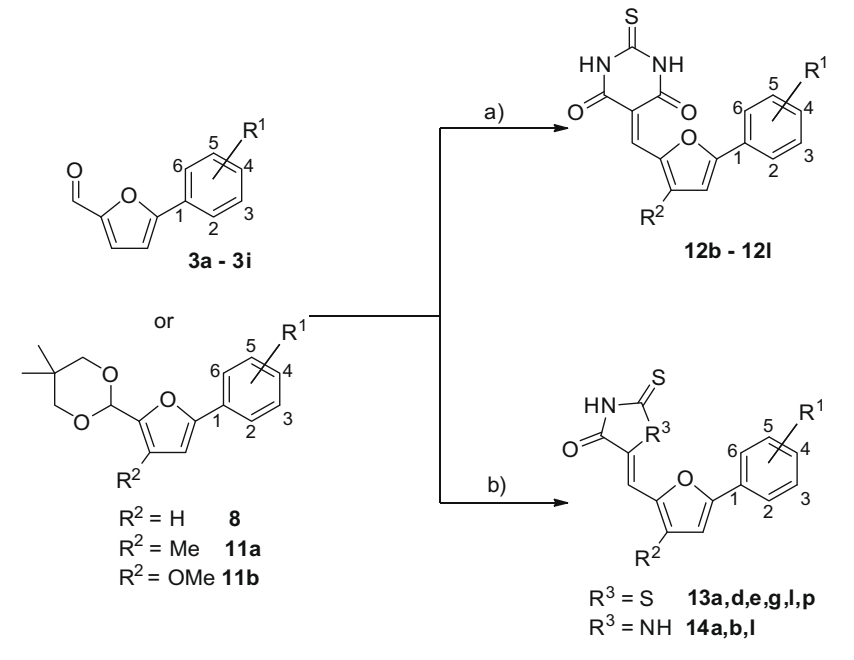

Scheme 4. Knoevenagel condensation for the assembly of final compounds $\mathbf{1 2}, 13$ and 14. Reagents and conditions: (a) 2-thiobarbituric acid, concd $\mathrm{HCl}, \mathrm{EtOH}, \mathrm{rt}$; (b) for $\mathrm{R}^{3}=\mathrm{S}$ : rhodanine, $\beta$-alanine, $\mathrm{AcOH}, 20^{\circ} \mathrm{C}$; for $\mathrm{R}^{3}=\mathrm{NH}$ : thiohydantoin, $\beta$-alanine, $\mathrm{AcOH}, 120^{\circ} \mathrm{C}$.

inferior yields or no coupling product at all. Better results were obtained when employing a Heck reaction between the protected furfural derivatives and a suitable functionalized phenyl halide. The reaction conditions reported by McClure et al. ${ }^{13}$ using $\mathrm{Cy}_{3} \mathrm{P}$ as ligand in DMF at $110^{\circ} \mathrm{C}$ were found to be most suitable for this transformation. The obtained coupling products were then further functionalized to furnish the desired compounds necessary for the following condensation step (Scheme 3).

The condensation reactions with thiobarbituric acid, rhodanine and thiohydantoin were carried out as described in literature. ${ }^{14,15}$ When reacted in ethanol with acid catalyst, thiobarbituric acid and the substituted phenyl furfural derivatives readily gave the desired condensation products, which could be easily isolated by simple filtration. Condensation reactions with rhodanine and thiohydantoin were carried out in acetic acid in the presence of $\beta$-alanine (Scheme 4).

In summary a new hit compound exhibiting anti IN activity and moderate inhibition of HIV-1 cell replication was identified by the use of an improved virtual screening protocol. Subsequently synthesis of a small family of structurally related compounds was accomplished establishing SAR of these inhibitors. Further studies including the elucidation of the mechanism of action on this novel family of potential IN inhibitors are ongoing in our laboratories and will be reported in due course.

\section{Acknowledgments}

This work was supported by the European Union (TRIoH Consortium, LSHB-2003-503480 and THINC, HEALTH-2007-2.3.2-1). ASINEX is acknowledged for partial support of this work and Molecular Discovery for access to the GRID code.

\section{References and notes}

1. (a) Meadows, D. C.; Gervay-Hague, J. Chem. Med. Chem. 2006, 1, 16; (b) De Clerq, E. J. Med. Chem. 2005, 48, 1297.

2. (a) Yin, P. D.; Das, D.; Mitsuya, H. Cell. Mol. Life Sci. 2006, 63, 1706; (b) Imamichi, T. Curr. Chem. Pharm. Des. 2004, 10, 4039.

3. Reviews: (a) Esposito, D.; Craigie, R. Adv. Virus Res. 1999, 52, 319; (b) AssanteAppiah, E.; Skalka, A. M. Adv. Virus Res. 1999, 12, 2231.

4. Selected reviews include: (a) Dayam, R.; Gundla, R.; Al-Mawsawi, L. Q.; Neamati, N. Med. Res. Rev. 2008, 28, 118; (b) Pommier, Y.; Johnson, A. A.; Marchand, C. Nat. Rev. Drug Discovery 2005, 4, 236; (c) Hazuda, D. J.; Felock, P.; Witmer, M.; Wolfe, A.; Stillmock, K.; Grobler, J. A.; Espeset, A.; Gabryelski, L.; Schleif, W.; Blau, C.; Miller, M. D. Science 2000, 287, 646. 
5. Evering, T. H.; Markowitz, M. Drugs Today 2007, 12, 865

6. Summa, V.; Petrocchi, A.; Bonelli, F.; Crescenzi, B.; Donghi, M.; Ferrara, M.; Fiore, F.; Gardelli, C.; Gonzalez Paz, O.; Hazuda, D. J.; Jones, P.; Kinzel, O.; Laufer R.; Monteaguado, E.; Muraglia, E.; Nizi, E.; Orvieto, F.; Pace, P.; Pescatore, G. Scarpelli, R.; Stillmock, K.; Witmer, M. V.; Rowley, M. J. Med. Chem. 2008, 51 5843.

7. Mugnaini, C.; Rajamaki, S.; Tintori, C.; Corelli, F.; Massa, S.; Witvrouw, M. Debyser, Z.; Veljkovic, V.; Botta, M. Bioorg. Med. Chem. Lett. 2007, 17, 5370.

8. Tintori, C.; Corradi, V.; Magnani, M.; Manetti, F.; Botta, M. J. Chem. Inf. Model 2008, 8, 2166.

9. http://www.asinex.com/prod/gold.html (accessed June 2007).

10. Deprez, E.; Barbe, S.; Kolaski, M.; Leh, H.; Zouhiri, F.; Auclair, C.; Brochon, J.-C.; Le Bret, M.; Mouscadet, J.-F. Mol. Pharm. 2004, 65, 85.
11. Malinowski, S. Polish J. Chem. 1953, 27, 54

12. Huff, B. E.; Koenig, T. M.; Mitchell, D.; Staszak, M. A. In Organic Syntheses, 3rd ed.; Smith, A. B., Eds.; Organic Synthesis; 1997, Vol. 75, pp 53-59.

13. McClure, M. S.; Glover, B.; McSorley, E.; Millar, A.; Osterhout, M. H. Roschangar, F. Org. Lett. 2001, 3, 1677.

14. Dox, A. W.; Pl aisance, G. P. J. Am. Chem. Soc. 1916, 38, 2164.

15. Unangst, P. C.; Connor, D. T.; Cetenko, W. A.; Sorenson, R. J.; Kostlan, C. R.; Sircar, J. C.; Wright, C. D.; Schrier, D. J.; Dyer, R. D. J. Med. Chem. 1994, 37, 322.

16. Biological testing was performed as reported earlier: Dubois, M.; Bailly, F.; Mbemba, G.; Mouscadet, J.-F.; Debyser, Z.; Witvrouw, M.; Cotelle, P. J. Med. Chem. 2008, 51, 2575. 